\title{
Social Sciences
}

2017; 6(6): 182-186

$\mathrm{http}: / /$ www.sciencepublishinggroup.com $/ \mathrm{j} / \mathrm{ss}$

doi: 10.11648/j.ss.20170606.16

ISSN: 2326-9863 (Print); ISSN: 2326-988X (Online)

\section{The Understanding of the Words to "Seek God" and to "Live" in Amos 5:4-6}

\author{
Milton Thorman Pardosi \\ Department of Philosophy, Universitas Advent Indonesia, Bandung, Indonesia
}

\section{Email address:}

mtpardosi@gmail.com

\section{To cite this article:}

Milton Thorman Pardosi. The Understanding of the Words to "Seek God" and to "Live" in Amos 5:4-6. Social Sciences. Vol. 6, No. 6, 2017, pp. 182-186. doi: 10.11648/j.ss.20170606.16

Received: September 18, 2017; Accepted: November 20, 2017; Published: December 12, 2017

\begin{abstract}
The book of Amos is a special book which brings a special message about God's justice and judgment upon nations (Israel, Judah, etc.). Nevertheless, for Israelites, Amos had a particular message for God assigned him to preach among them. Two issues would be discussed in this study. They are: (1) What is the meaning of the word to "seek" God in Amos' understanding? (2) What is the meaning of the word to "live" in Amos' understanding. Then, the purpose of the study is to find the meaning of the words to "seek" God and to "live" in Amos' understanding. Amos' message is to call Israel to repent from her sins and to seek God as the only way to free of God's punishment and judgment. God would punish Israel because she did not repent from her sins although God sent many prophets to remind her. At that time, Israel involved in social and religious sins. In her religious sins, Amos appointed Bethel, Gilgal, and Beersheba as the main sacred cities among Israel where Israel began wicked practices. Instead of worshiping God, Israel worshiped idols and evoked social sins among Israelites. God really wanted to save Israel from great disasters that would come to her. It can be seen from the way that God offered to Israel and invited her to come to Him, repent and obey His commandments, but Israel never repented from her sins. As the consequence of Israel's sin, God let her to be captivated by other nations as mentioned by Amos. The key word in Amos 5:4-6 is to "seek God." For Amos, "to seek God" means seeking good, doing justice and rightness, worshiping God in the right way, and seeking the word of the Lord (Amos 5:14, 15; 8:12). Then, the assurance that God promised to Israel that "you may live" would happen. "Live" means renewed from sins, enjoy God's mercy as His children, to live more fully, and at the end, to have eternal life in heaven.
\end{abstract}

Keywords: Seek, Live, Judgment

\section{Introduction}

Come closer to God which means to repent and to seek God are the only ways for human beings to live and free of God's judgments as mentioned by Amos in his message. This is because God is the source of judgment, but He also is the source of mercy and grace [1].

In English or other versions of Bible, the book of Amos is the thirtieth book in the Old Testament. But in Hebrew Bible, it is the fifteenth book. Moreover, the book itself is the third book of twelve Minor Prophets [2].

The name of Amos means "borne; a burden" [3]. He was a "shepherd" at Tekoa (Southern Kingdom of Judah) and also a "grower of sycamore trees" [4] when God encountered him. But, however, he preached in the Northern kingdom of Israel. Amos was "contemporary with Hosea, Joel and Isaiah, and prophesied a little sooner than Isaiah" [5].

However, there are two issues were discussed in this study. First, what is the meaning of the word to "seek God" in Amos' understanding? The other one is, what is the meaning of the word "to live" in Amos' understanding?

Therefore, the purposes of the study were related to the two issues that have been mentioned above. They are: first, to find the meaning of the word to "seek God" in Amos" understanding. The last is to find the meaning of the word "to live" in Amos' understanding.

Throughout the study, the writer focuses this study to the meaning of the verbs to "seek God" and to "live" in Amos 5:4-6 and its context in the whole book of Amos. In other words, the study would not do a deep research about the two verbs that were being discussed in their usages in the rest of Old Testament's books. 
In finishing this study, the writer applied the grammaticalbiblical method of exegesis in a simple way in order to solve the problems being undertaken. The immediate context in Amos 5:4-6 and the larger context of chapters 5 and the book of Amos would be examined. The Bible itself was the primary source. Secondary sources included theological dictionaries, concordances, lexicons, grammars, commentaries. Relevant periodicals were being consulted in order to seek other relevant literature.

\section{The Book of Amos}

The book of Amos is a unique book. This book has an introduction which is different from other book. The first words are "the words of Amos." Moreover, Amos, as the writer, is the only writer who tells what his occupation was before God called him [6].

\subsection{Theme}

The theme of the book of Amos is "God's justice" [7]. Amos' message about God's justice is not only for Israel and Judah but also for the surrounding nations (Amos 1:3-2:3) because God is God of all nations. In other words, if Israel's neighbors do not repent from their sins, God will also against them as He does with Israel and Judah.

But Amos has a special message to Israel which is "to call the attention of God's people to their sins, and if possible to bring them to repentance" [8]. Later, at the end of his book, "Amos closes his book with a glorious picture of the ultimate triumph of righteousness over iniquity" [9], [10].

\subsection{Textual and Literary Analysis of Amos 5:4-6}

Amos 5:4:6 is a part of Amos 5:1-17 [11]. This poetry, which is an appeal, is begun with "for thus says Yahweh" (v. 3 [12] is started with "for thus says the Lord God") and be closed with God's punishment upon Israel if she does not seek God and repent from her sins. The word "Bethel" which appears three times in the passage is the clue that this passage is ended in v. 6.

According to David A. Hubbard, vv. 1-3 is lamentation that functions as announcement; vv. 4-6 is an oracle; v. 7 is accusation [13] (It is the first of the woes in the book of Amos [moral corruption of Israel]) which is started with a metaphor [14]. The chiastic patterns are also another sign of it.

(1) Bethel (A) verse 5

Gilgal (B) verse 5

Beersheba $(\mathrm{C})$ verse 5

Gilgal (B') verse 5

Bethel (A') verse 5

(2) Seek Me (A) verse 4

Do not seek $(B)$ verse 5

Seek Yahweh (A') verse 6

In Hebrew language, there are some important things that need to be observed in this passage. The first one is in v. 6 compare to Septuagint which is same with Hosea 10:15 (house of Israel is house of Bethel or house of God). The next one is negative form ( $l o^{\prime}$ and ' $a l$ ). Amos uses ' $a l$ (immediate or temporary) for Bethel but for Gilgal and Beersheba, he uses lo' (permanent) [15]. It seems Amos has something important ideas about those three places.

The concern of Amos was to appeal Israel to repent and to seek God. These are the only ways in which Israel could free from God's judgment and if not, Israel would face God's punishment. Seek the Lord (repentance) is theme of the passage being studied.

"To seek" (Qal, Imperative) is the key word. The word "seek" in Hebrew is $d r \check{s}$. "It means care about, inquire (of), consult, seek, require (of), study, investigate, examine, and ask. This verb occurs 165 times in the Old Testament: 1 and 2 Chr. (41x), Ps. (25x), Ezek. (15x), 14x in Deut., 1 and 2 Kings, and Isa, Jer. (9x),..., Amos." (4x: Am. 5:4, 5, 6, 14), etc. [16]. Amos uses this word with "a sense of urgency; it is the last hope in the face of Judgment" [17]. since this word is followed with "live" (Qal, Imperative). So, by understanding these points, a good translation can be prepared. The translation [18] is:

v. 4 for thus says Yahweh to the house of Israel, seek Me and you may live

v. 5 but do not seek (Me) at Bethel (the house of God), and never enter into Gilgal nor cross over Beersheba, for Gilgal shall surely go into exile and Bethel (the house of God) will become nothing [19],

v. 6 seek Yahweh and you may live, lest He rush (upon you) like a flame (fire) O House of Joseph and it consumes (you) with none to quench (it) O House of God.

\subsection{Historical Analysis}

Amos lived at the time of Uzziah king of Judah (2 Kings 15:1-7; 2 Chr. 26:1-23), and Jeroboam the son of Joash king of Israel or Jeroboam II (2 Kings 15:23-29). "He preached about 760 B.C., less than forty years before the end of the Northern Kingdom of Israel" [20]. At that time, "both Israel and Judah were prosperous. And under Jeroboam II, Israel was at the zenith of its power" [21].

There are three places which are important as Amos mentioned in Amos 5:4-6. The first one is Bethel (the house of God which named by Jacob [Gen 28:19]). At that time, "Bethel, instead of being a place for the worship of the true God, had become the temple of an idol, and so had become nothingness" [22]. The house of God (Bethel) became the house of gods (idol).

P. J. M. Southwell says: Hosea (esp. 10:5) seems to call the sanctuary Beth-Aven, house of iniquity, because of this. Beth-Aven was Bethel at the time of Hosea and Amos. Jeroboam I build a temple at Bethel, and he put there a golden calf (I Kings 12:28-30) as a cult object, "presumably with the intention of rivaling the temple of Solomon in Jerusalem by giving Yahweh a syncretistic flavor." For Amos, Bethel is the prime target of his message $(7 \mathrm{x}$ : Amos $3: 14 ; 4: 4 ; 5: 5,6 ; 7: 10,13)$. At the time of Josiah's reform, Josiah demolished the altar and high place at Bethel, (2 Kings 23:15) as mentioned by a man of God form Judah who 
came to Bethel at the time of Jeroboam I (I Kings 13:1-34) and repeated by Amos [23], [24].

The next place is Gilgal. "Gilgal was the place where Israel's spiritual reproach was rolled away in the days of Joshua (Josh. 5:1-12)." Gilgal means roll away (words-play: gilgal galoh yigleh) [25]. "Gilgal, the first promised land encampment in the conquest, was a worship center since Joshua circumcised the conquest generation there" [26]. But Israel began wicked practices at Gilgal at the time of Hosea and Amos [27]. And in Hosea 12:12, indeed, "Gilgal had remained a sacred site for animal sacrifice in Hosea's day, the context suggests that the offerings at Gilgal were not sanctioned by God" [28].

The last place is Beersheba. This place was very important because it had very close association with Abraham (Gen. 22:19), Isaac (Gen. 26:23), and Jacob (Gen. 46:1-5). "Apparently there was such a high place at Beersheba in the days of Amos during the eight century B.C. (Amos 5:5; $8: 14)$, and Josiah's reform in the seventh century rooted out the high places, including the one at Beersheba (2 Kings 23:8)." Beersheba is repeated two times [29], [30]. In conclusion, the point is even Israel was in prosperous in economic and politic, but in spiritual, Israel did wicked things through worshiping another gods in Bethel, Gilgal, and Beersheba.

The question is what kind of sins that Israel did in the book of Amos that pushed God to punish her. There were two kinds of sin that they did:

1. Social sins.

"The social sins of Israel involved both illegal conduct and a selfish abuse the law. This included bribery [31]; dishonest commerce [32]; and even violence and looting [33]; as well as subtle abuse such as the imposition of unreasonable rent or taxes on the poor [34]. The selling of the innocent and helpless into slavery was not beyond them [35]. Amos describes even the women as 'cows of Bashan,' powerful and greedy for all they could get through their husband's abusive oppression of the poor" [36], [37].

2. Religious sins.

Israel "proudly displayed their worship in public (Amos $4: 4-5 ; 6: 8)$... Their worship was mere show and not from the heart. Furthermore, their worship was syncretistic and reflected a perverted view of God.... Israel integrated the pagan custom of ritual prostitution that was the norm for the surrounding nations (2:7). Their religious practice essentially treated God just like the capricious gods of the pagan nations around them, which could be pacified and manipulated by ritual $(4: 13 ; 5: 8-9 ; 8: 14)$ " [38]. Those were the reason wherein God had to punish Israel because of her sins against God and she did not repent from her sin.

\section{Interpretation}

The word "seek God" is very important in Amos' message as mentioned before. For Amos "to seek God required obedience to his Law, making His will one's own, living in communion with him," [39] or "living one's whole life in accordance with God's law (5:14) and offering Him the 'spiritual' worship of praise and obedience (5:21-23)" [40]. But for the Israelites "to seek God meant to offer worship to the nation's divinity, to go on pilgrimage to the holy places, to observe the traditional ritual."

The word $d r \check{s}$ or "to seek" appears 165 times in the Old Testament. It means that "to seek God" is also an important point in the Old Testament as well as in New Testament (Deut. 4:29; 2 Chr. 14; 4; Isa. 55:6, Matt. 6:33; Luke 11:9; Col. 3:1; Romans 2:7, etc.). The objects of "to seek God" are justice and good (Amos 5:14, 15), and the word of the Lord (Amos 8:12) as mentioned by Amos [41]. In addition to it, "to seek God" also means "returns to the covenant stipulations not only by the negation of illegitimate cultic activities and places, but also by commitment to a moralethical lifestyle conformed to the covenant" [42].

As the result of seeking God, Amos says that Israel may live (Qal imperative). "Live" here means national restoration of Israel, return to life or rebirth [43], or free from God's judgments upon her. "Live" does not mean that human kind will never face the death because everyone someday will die (Gen. 3:19), but live here means not only free from being killed by Israel's enemies (physical death) but renewed from sins, to live more fully, enjoy God's mercy as His children [44].

\section{Relevance}

Amos' emphasizing to seek God is not only for Israel but also for all human beings who live at this time. Now, people are facing the same problems (worship another god and doing evil) and God also will punish whoever doing those sins (Rev. 20:12-15).

As mentioned by Amos, however, the only way to live and free from God's judgment is by seeking God, to come closer to Him, repent and follow Him by keeping His laws (to do the right thing in the right way). It begins "in the heart (i.e., the mind and the will); and in the practice of justice and righteousness, in attachment to the good and detachment from the bad, the presence of God become more real" [45]. No matter who we are, seeking God through obedience of God's will is the only way to enjoy His love and mercy while living on the earth (present) and the eternal life in heaven (future).

\section{Conclusion}

The message of Amos is a message for all age. Now, people are facing the judgment day, and all of men will be judged according to what they have done. But God gives assurance that whoever seeks and accepts Him as personal savior, and obey His commandments will live.

For Amos, "to seek God" means seeking good, doing justice and rightness, worshiping God in the right way, and seeking the word of the Lord (Amos 5:14, 15; 8:12). Then, the assurance that God promised to Israel that "you may live" would happen. "Live" means renewed from sins, enjoy God's 
mercy as His children, to live more fully, and at the end, to have eternal life in heaven.

Finally, who we worship in the church and what we do after go back from the church are more important than going to the church and doing some rituals there. What we believe and what we do must be in harmony.

\section{References}

[1] Amos 9:8-15 (New King James Version).

[2] "The designation 'minor prophet' derives from Jewish tradition. It is used for the book of the Twelve Prophets, that is, the short or small prophetic books outside of the long ones such as Isaiah, Jeremiah, and Ezekiel." Gerhard F. Hasel, Understanding the Book of Amos, Grand Rapids: Baker, 1991, p. 17. The first one is Hosea, and the second one is Joel. For more details please read: David Allan Hubbard, Joel \& Amos, Tyndale Old Testament Commentaries, Vol. 22B, Leicester, England: Inter Varsity, 1989, pp. 88-89.

[3] George W. Coats, "Amos," available from http://mbsoft.com/believe /txs/amos.htm. Accessed on February 4th, 2004.

[4] Amos 1:1; 7:14, 15 (New King James Version).

[5] "The Book of Amos," available from hhtp://www/cce.org/w/wesley/notes/amos.html\#chapter-V. Accessed on February 4th, 2004.

[6] Thomas J. Finley, The Wycliffe Exegetical Commentary: Joel, Amos, Obadiah, Chicago: Moody, 1990, p. 105.

[7] Jon L. Dybdahl, A Practical Guide to Abundant Christian Living in the Books of Hosea-Micah, The Abundant Life Bible Amplifier, Boise, ID: Pacific Press, 1996, p. 108.

[8] "Theme" (Amos), Seventh-day Adventist Bible Commentary $(S D A B C)$, ed. Francis D. Nichol, Vol. 4, Washington, DC: Review \& Herald, 1955, p. 954.

[9] "Theme" (Amos), Seventh-day Adventist Bible Commentary $(S D A B C)$, ed. Francis D. Nichol, Vol. 4, Washington, DC: Review \& Herald, 1955, p. 954.

[10] Amos 9:11-15 (New King James Version).

[11] Amos 5:1-17 is a unit. "It begins with the announcement of a lament/elegy for the nation in v. 1 and ends with a graphic portrayal of the nation at mourning." Amos 5:1-3 is lamentation over the destruction of Israel. Amos 5:18-27 is a woe oracle and is continued with other woe in chapter 6 . Douglas Stuart, Amos, Word Biblical Commentary (WBC), Vol. 31, Waco, TX: Word, 1987, p. 344.

[12] Amos 5:3 is ended with the sign "Soph Pasuq." "Soph Pasuq" sign means "end of verse." J. Weingreen, A Practical Grammar for Classical Hebrew, $2^{\text {nd }}$ ed., New York: Oxford University Press, 1959, p. 251. In other words, Amos 5:4 is a new part or section or different from verse 3 .

[13] Hubbard, 164. V. 7 is the first of the woes in the book of Amos (moral corruption of Israel).

[14] "Wormwood is a plant of the genus Artemisia, with a very bitter taste. It is a symbol that the moral corruption of Israel was so great that "justice was converted into bitterest injustice." "Wormwood" (Amos 5:7), Seventh-day Adventist Bible Commentary (SDABC), ed. Francis D. Nichol, Vol. 4, Washington, DC: Review \& Herald, 1955, p. 970.

[15] The word 'al (in Hebrew) is used "for the occasional contingent prohibition and the word $l o$ ' (in Hebrew) used for an absolute prohibition, are here used indiscriminately." J. Alberto Soggin, The Prophet Amos: A Translation and Commentary, trans. John Bowden, England: SCM, 1987, p. 84.

[16] David Denninger, New International Dictionary of Old Testament Theology \& Exegesis (NIDOTTE), ed. Willem A. Van Gemeren, Vol. 1, Grand Rapids: Zondervan, 1997, p. 993. The synonym of the word daraš is baqaš. This verb occurs 225 times in the Old Testament (222x in Piel stem and 3x in Pual stem [Esth. 2:23; Jer 50:20; Ezek 26:21]). This verb does not occur in Joel, Obadiah, Jonah, Micah, Habakkuk, and Haggai. This verb occurs one time in the book of Amos (Amos 8:12). In Piel stem it means "seek, find, look for (an object)." In Pual stem it means "be sought (for), be searched, be examined." Chitra Chetri, New International Dictionary of Old Testament Theology \& Exegesis (NIDOTTE), ed. Willem A. Van Gemeren, Vol. 1, Grand Rapids: Zondervan, 1997, pp. 720-1.

[17] "Those who do not seek Yahweh are the wicked, and their punishment is announced." David Denninger, New International Dictionary of Old Testament Theology \& Exegesis (NIDOTTE), ed. Willem A. Van Gemeren, Vol. 1, Grand Rapids: Zondervan, 1997, p. 998.

[18] Francis I. Andersen and David Noel Freedman, Amos, Anchor Bible (AB), Vol. 24A, Garden City, NY: Doubleday, 1989, pp. 477-8. The translation in Italic is mine.

[19] It can be translated as "for the rolling city (Gilgal) rolls thence, and the house of God (Bethel) comes to an utter end." C. Von Orelli, The Twelve Minor Prophets, Trans. J. S. Banks, Minneapolis, MN: Klock and Klock, 1987, p. 128.

[20] Ganoune Diop, "The Remnant Concept as Defined by Amos," Journal of the Adventist Theological Society 7/2 (1996), p. 68.

[21] "Historical Setting" (Amos), Seventh-day Adventist Bible Commentary (SDABC), ed. Francis D. Nichol, Vol. 4, Washington, DC: Review \& Herald, 1955, p. 953.

[22] "Beth-el" (Amos 5:5), Seventh-day Adventist Bible Commentary (SDABC), ed. Francis D. Nichol, Vol. 4, Washington, DC: Review \& Herald, 1955, p. 970.

[23] P. J. M. Southwell, New International Dictionary of Old Testament Theology \& Exegesis (NIDOTTE), ed. Willem A. Van Gemeren, Vol. 4, Grand Rapids: Zondervan, 1997, p. 441.

[24] Amos 3:14 (New King James Version).

[25] "Amos 5: The Offerings God Hates," available from http://calvarychapel.com/ccbcgermany/commentaries/3005.ht m. Accessed on February $4^{\text {th }}, 2004$.

[26] Douglas Stuart, Amos, Word Biblical Commentary (WBC), Vol. 31, Waco, TX: Word, 1987, 346. Compared to Joshua $5: 2-12$.

[27] Hosea 9:15 (New King James Version).

[28] Mark F. Rooker, New International Dictionary of Old Testament Theology \& Exegesis (NIDOTTE), edited by Willem A. Van Gemeren, Vol. 4 Grand Rapids: Zondervan, 1997, p. 684. Gilgal is repeated three times in the book of Amos (Amos 4:4; 5:5,5). 
[29] Howard F. Vos, New International Dictionary of Old Testament Theology \& Exegesis (NIDOTTE), edited by Willem A. Van Gemeren, Vol. 4, Grand Rapids: Zondervan, 1997, p. 440.

[30] Amos 5:5; 8:14 (New King James Version).

[31] Amos 5:12 (New King James Version).

[32] Amos 8:5 (New King James Version).

[33] Amos 3:10; 6:3 (New King James Version).

[34] Amos 5:11(New King James Version).

[35] Amos 2:6; 8:6 (New King James Version).

[36] "The Theology of Amos," available from http://www.homestead.com/ danwagner/files/ThAmos.htm. Accessed on February 12 2004.

[37] Amos 4:1 (New King James Version).

[38] "The Theology of Amos," available from http://www.homestead.com/ danwagner/files/ThAmos.htm. Accessed on February 12 2004.
[39] Archard and S. Paul Re'emi, Amos \& Lamentations: God's People in Crisis, Edinburgh: Handsel, 1984, p. 40.

[40] Bernard Thorogood, A Guide to the Book of Amos, London: S. P. C. K., 1971, p. 56.

[41] Amos 5:4 is parallel with Amos 5:14-15 and 8:12 (New King James Version).

[42] Ganoune Diop, "The Remnant Concept as Defined by Amos," Journal of the Adventist Theological Society 7/2 (1996), p. 74.

[43] "Ideally, life for the people of Yahweh is more than the absence of death. It is, in every sense of the word, to be well." Terry L. Brensinger, Brensinger, New International Dictionary of Old Testament Theology \& Exegesis (NIDOTTE), edited by Willem A. Van Gemeren, Vol. 2, Grand Rapids: Zondervan, 1997, p. 110.

[44] Bernard Thorogood, A Guide to the Book of Amos, London: S. P. C. K., 1971, p. 58.

[45] Francis I. Andersen and David Noel Freedman, Amos, Anchor Bible (AB), Vol. 24A, Garden City, NY: Doubleday, 1989, p. 482. 